\section{Adam Ryszard Sikora OFM}

Uniwersytet im. Adama Mickiewicza, Poznań

arsikora@onet.eu

DOI: http://dx.doi.org/10.12775/BPTh.2016.036

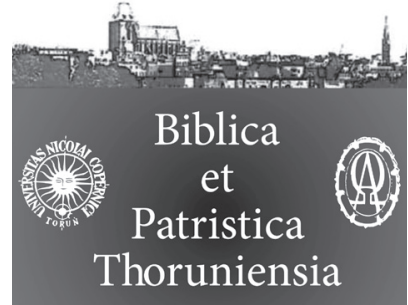

9 (2016) 4: 99-114

ISSN (print) 1689-5150

ISSN (online) 2450-7059

\title{
"W domu Ojca Mego mieszkań jest wiele" (J 14,2). Perspektywa chrześcijańskiej nadziei
}

\section{"In my Father's house there are many dwelling places" (Jn 14:2). Prospect of Christian Hope}

Streszczenie. Geneza, rozwój i znaczenie zagadnienia eschatologii należą do kwestii najbardziej spornych zarówno w perspektywie Starego, jak i Nowego Testamentu. Odnosi się ono zarówno do większych partii wypowiedzi, jak i do pojedynczych zdań zawartych w Biblii. Szczególnego znaczenia kwestia ta nabiera, gdy weźmie się pod uwage Ewangelię według św. Jana. W Księdze tej faktem w pełni eschatologicznym dla ucznia Chrystusa jest akt wiary, decydujący o posiadaniu życia wiecznego już teraz, choć św. Jan nie przekreśla także eschatologii przyszłej, zapowiadającej sąd i pełny udział w chwale Jezusa uwielbionego. Jednym ze zdań budzących niesłabnące zainteresowanie jest wypowiedź Jezusa zawarta w J 14,2: „W domu Ojca mego jest mieszkań wiele”. Próba wyjaśnienia tych słów zostaje podjęta w niniejszym artykule przede wszystkim na postawie analizy najbliższego kontekstu (J 14,1-3), nie wykluczając oczywiście także odwołania się do innych tekstów Czwartej Ewangelii. Kluczem hermeneutycznym służącym do interpretacji tytułowych słów artykułu są słowa Jezusa stanowiące jeden z czterech elementów opisujących rzeczywistość eschatologiczną w J 14,2-3: „A gdy odejdę i przygotuję wam miejsce, przyjdę powtórnie i zabiorę was do siebie, abyście i wy byli tam, gdzie Ja jestem" (J 14,3). Przez pryzmat słów wskazujących na istotę tej nowej rzeczywistości, a mianowicie na fakt zjednoczenia uczniów z Jezusem, interpretowane będą pozostałe trzy elementy: „dom Ojca”, „mieszkań wiele” i „miejsce”. Wszystkie one bowiem odnoszą się do rzeczywistości trwałej wspólnoty, z podkreśleniem pewnych właściwych jej odcieni. I choć tytułowe słowa nie poszerzają naszej wiedzy na temat „jak jest w niebie”, to podkreślają z całą mocą prawdę o prawdziwym życiu, które jest możliwe tylko wówczas, gdy żyjemy na stałe z tymi, których kochamy.

Summary. Origin, development and meaning of the problem of eschatology belong to the most controversial issues, both in the perspective of the Old and the New Testament. It refers to longer passages as well as to isolated phrases included in the Bible. The issue acquires a special significance with reference to the Gospel of St. John. In 
this Book, it is the act of faith that for Christ's disciple constitutes a fully eschatological fact deciding about having eternal life right now, although St. John does not eliminates the 'future' eschatology indicating judgment and a full participation in the glory of the worshipped Jesus. One of the sentences which arouses continued interest is Jesus' statement included in Jn 14:2: 'in my Father's house there are many dwelling places'. The article tries to explain the phrase first of all on the ground of the analysis of the next context (Jn 14:1-3), but certainly it does not exclude references to other texts of the Fourth Gospel. The hermeneutic key for the interpretation of the title words of the article are Jesus' words being one of four synonymous elements describing eschatological reality in Jn 14:2-3: 'and if I go and prepare a place for you, I will come back again and take you to myself, so that where I am you also may be.' (Jn 14:3). The remaining three elements: 'Father's house', 'many dwelling places' and 'a place' are to be interpreted through the words talking about the essence of this new reality, i.e. the disciples' union with Jesus. Since they all concern a solid communion stressing some of their characteristic shades. And although the title words do not extend our knowledge as to "what is heaven like', they strongly emphasize the truth about real life that is possible only when we permanently live with the ones we love.

Słowa kluczowe: eschatologia; Ewangelia według św. Jana; dom Ojca; mieszkanie; wspólnota zbawionych.

Keywords: eschatology; Gospel of St. John; Father's house; dwelling place; community of the redeemed.

Tiewątpliwie, zagadnienie eschatologii w Biblii należy do kwestii najbarnosi się to tak do szerszych staro- i nowotestamentalnych bloków wypowiedzi o przyszłym życiu po śmierci, jak i do pojedynczych sformułowań, które nie przestają intrygować czytelników Pisma Świętego.

Specyficzne ujęcie kwestii eschatologicznych prezentuje autor Ewangelii według św. Jana. Decydującym, w pełni eschatologicznym faktem jest dla ucznia Chrystusa w tej Ewangelii akt wiary. Ten bowiem, kto wiarę przyjmuje, już posiada życie wieczne (J 3,36), przeszedł ze śmierci do życia (J 5,26), nie podpada pod sąd. Natomiast ten, który odrzuca zbawcze posłannictwo Jezusa, ściąga na siebie już teraz eschatologiczny wyrok $(\mathrm{J} 3,18)$. Stąd też w perspektywie czasu, teraźniejszość odgrywa rolę decydującą ${ }^{2}$. Jan jednak nie przekreśla eschatologii przyszłej, gdyż zapowiada zarówno przyszły sąd (J 5,27nn; 15,6),

1 L. Stachowiak, Ewangelia, s. 415.

2 Chodzi o tzw. „eschatologię zrealizowaną”. Autorem tego pojęcia był C.H. Dodd, The Parables. Za J. Kozyra, Eschatologia, s. 227. 
jak i oczekiwany w przyszłości pełny udział w chwale Jezusa uwielbionego, po zmartwychwstaniu ciał (J 17,24-26). Pogląd zatem o eschatologii zrealizowanej należy przyjmować z ograniczeniem, dodając, że chodzi o eschatologię zrealizowaną jedynie częściowo ${ }^{3}$.

Jednym z tekstów w Nowym Testamencie budzącym niegasnące zainteresowanie $^{4}$, jest przywołana w tytule wypowiedź Jezusa zapowiadająca czasowe rozstanie z uczniami, pochodząca właśnie z Janowej Ewangelii: $W$ domu Ojca mego jest mieszkań wiele (J 14,2a). Zdanie to, jak przypuszcza R. Brown, może być „aluzją do paruzji - jednym z nielicznych przykładów eschatologicznej myśli autora czwartej Ewangelii" ${ }^{5}$. Jednocześnie uważa on, że te dwa wersety (J 14,2-3) „W interpretacji należą do ekstremalnie trudnych"6.

Celem niniejszego artykułu będzie próba dania odpowiedzi na pytanie, jak zasadniczo aktualnie odczytuje się te słowa skierowane wówczas do zalęknionych uczniów, by i w dzisiejszych wyznawcach Jezusa neutralizowały one paraliżujący lęk i umacniały nadzieję, przypominając o ostatecznym celu ludzkiego życia, jakim jest życie wieczne.

Najbliższym kontekstem do wypowiedzi o domu Ojca, w którym jest mieszkań wiele, są pierwsze trzy wersety rozdziału czternastego (J 14,1-3). Wersety te znajdują się w drugiej części Ewangelii Janowej, w tzw. Mowach Pożegnalnych Jezusa $(13,1-17,26)$, skierowanych wyłącznie do Jego uczniów, których Pan, w obliczu zbliżającej się swojej męki i śmierci krzyżowej, pragnie przygotować na przeżycie czasu pozornego tryumfu ciemności. Ścisła seria mów rozpoczyna się jednak dopiero od rozdz. 14, i obejmuje zarówno retrospektywną ocenę dotychczasowej działalności Jezusa, jak i wyjaśnianie sensu rozłąki Jezusa z uczniami.

Rozdział czternasty rozpoczyna się tak, jak wcześniejszy, od nawiązania do tematyki rozstania Mistrza z uczniami (13,1.33; 14,1nn). Do uczniów zebranych w wieczerniku Jezus zwraca się w słowach:

3 A. Jankowski, Eschatologia, s. 30; J. Kozyra, Eschatologia, s. 229.

4 Wypowiedź ta doczekała się licznych interpretacji już w starożytnych komentarzach pisarzy chrześcijańskich, ale także wielość współczesnych prób jej interpretacji w wielu publikacjach biblistów wskazuje na ciągłe pragnienie zgłębiania tego tematu.

5 R. Brown, I Bogiem było Słowo, s. 208.

6 Idem, Giovanni, s. 751. 
Niech się nie trwoży serce wasze. Wierzycie w Boga? I we Mnie wierzcie! W domu

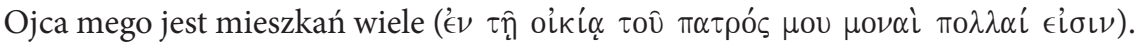
Gdyby tak nie było, to bym wam powiedział. Idę przecież przygotować wam miej-

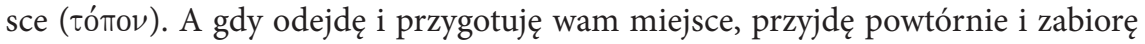
was do siebie, abyście i wy byli tam, gdzie Ja jestem.

Przerażonym zapowiedzią swego odejścia uczniom, Jezus wskazuje wpierw na możliwość pokonania tego lęku poprzez trwanie w wierze w Boga, i tym samym w wierze w Niego (por. 14,1), a następnie przez życie nadzieją na dom Ojca, w którym „mieszkań jest wiele”, a do którego to domu po krótkiej rozłące Jezus zabierze uczniów, by byli tam, gdzie On (por. 14,3). Pociechą jest więc również tymczasowość rozłąki z Jezusem.

Obrazowość wypowiedzi o „domu Ojca, w którym mieszkań jest wiele”, inspirowała komentatorów tego tekstu najczęściej albo do interpretacji dosłownej, zmierzającej do dokładniejszego opisania rzeczywistości nadprzyrodzonej, której „zasłona została nieco uchylona”, albo do interpretacji opierającej się na założeniu, że wypowiedź tę należy traktować jako metaforę mającą na celu przybliżenie jedynie istoty owej rzeczywistości. W ramach tych dwóch zasadniczych nurtów pojawiło się w historii wiele szczegółowych rozwiązań, ukazujących całe spektrum różnorodnego rozumienia tych znaczących słów Jezusa ${ }^{8}$.

W interesującym nas fragmencie J 14,2-3 zwracają na siebie uwagę wyrażenia bądź słowa, które zdają się odnosić do tej samej rzeczywistości, mieszczącej się w ramach terminologii tradycyjnej ówczesnego środowiska palestyńskiego.

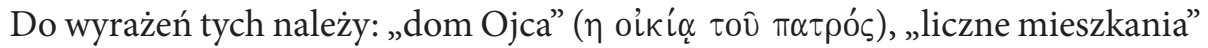
( jako rzeczywistości, „do której odchodzi Jezus”, i do której zabierze On swoich

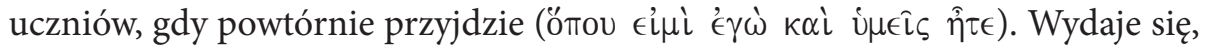
że to ostatnie określenie podpowiada sposób interpretacji trzech wcześniejszych. Pierwszym krokiem w wyjaśnieniu kwestii, jak rozumieć „wiele mieszkań” w „domu Ojca”, będzie więc próba ustalenia znaczenia słów o powtórnym przybyciu Jezusa i zabraniu uczniów, by przebywali w „miejscu”, gdzie On będzie. Dopiero potem przeprowadzona zostanie analiza pozostałych wyrażeń i ukazane zostaną zachodzące między nimi relacje.

7 A. Paciorek, Ewangelia umiłowanego ucznia, s. 352.

8 Zob. zestawienie tych rozwiązań w: G. Fischer, Die himmlischen Wohnungen; J. McCaffrey, The House with Many Rooms, s. 29-35. 


\section{Miejsce (тótroc)}

Zapowiadając swoje odejście, Jezus wyjaśnia uczniom jego cel. Jest nim przy-

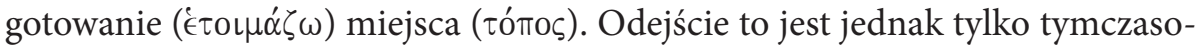
we, gdyż po przygotowaniu miejsca, Jezus zapowiada swój powrót i zabranie uczniów do siebie, tam, gdzie On jest. Uczeni są zasadniczo zgodni, że powtórne przybycie Jezusa nie odnosi się do chrystofanii po zmartwychwstaniu, będących dotykalnym i widzialnym dowodem tego, że Chrystus jako zmartwychwstały Pan jest obecny wśród uczniów, ale że odnosi się do paruzjị9 Niemniej różnią się już w tym, czy paruzję tę należy rozumieć jako godzinę śmierci chrześcijanina (Bultmann), czy jako Jego przybycie przy końcu czasów (Lagrange, Loisy, Barrett, Boismard), by dokonać eschatologicznego sądu nad światem ${ }^{10}$, czy ofiarowanie uczniom przez Jezusa już w ich ziemskiej egzystencji „współczesności ze swym wcieleniem, która da im radość w udręce”11, czy też przyjście w uczcie sakramentalnej (Hoskyns, Cullmann). Zdaniem J. Gnil$\mathrm{ki}^{12} \mathrm{w}$ tekście tym widzieć raczej należy, zgodnie z duchem Czwartej Ewangelii, przybycie Boga i Chrystusa do wierzącego w chwili śmierci. Wprawdzie uderzające jest podobieństwo obietnicy Jezusa do zapowiedzi paruzji w 1 Tes $4,16^{13}$, kiedy to przy powtórnym przyjściu Jezusa dokonuje się zjednoczenie z Nim Kościoła, ale w tekście Janowym, w przeciwieństwie do wypowiedzi św. Pawła, brak jest jakichkolwiek motywów paruzji: wskrzeszenia zmarłych czy pozostania przy życiu aż do paruzji ${ }^{14}$. R. Brown uważa, że fragment ten mógł pierwotnie odnosić się do paruzji finalnej, ale ponieważ paruzja nie nastąpiła zaraz po śmierci Jezusa, a uczniowie zaczęli umierać, dokonano reinterpretacji

9 A. Jankowski, Eschatologia, s. 78. J. Kozyra również podkreśla, że „tekst ten wyraźnie mówi o powtórnym przyjściu Jezusa, i o tym, że ten fakt wiąże się z życiem w jedności z Nim i Ojcem w niebie tych wszystkich, którzy uwierzyli w Niego (por. J 7,33; 8,21). Zob. Eschatologia, s. 233.

10 Np. C.S. Keener uważa, że w J 14,3 mowa jest o powtórnym przyjściu Jezusa „po zmartwychwstaniu umarłych w celu udzielenia Ducha Świętego". Zob. Komentarz historyczno-kulturowy, s. 216.

11 S. Mędala, Ewangelia, s. 89. Taki pogląd podzielają też m.in. Heise, Dodd, Lindars i Vouga.

12 J. Gnilka, Teologia, s. 389.

13 „Sam bowiem Pan zstąpi z nieba na hasło i na głos archanioła, i na dźwięk trąby Bożej, a zmarli w Chrystusie powstaną pierwsi. Potem my, żywi i pozostawieni, wraz z nimi będziemy porwani w powietrze, na obłoki naprzeciw Pana, i w ten sposób zawsze będziemy z Panem".

14 Ten pogląd podziela także R. Schnackenburg, The Gospel, s. 70. 
tego fragmentu, po czym dostrzegano w nim zabranie przez Jezusa wierzącego w chwili jego śmierci ${ }^{15}$. Także słowa obietnicy danej Piotrowi w J 21,15-19 zostaną później odniesione wyraźnie do jego śmierci ${ }^{16}$. Śmierć ucznia i paruzja występują tu w ścisłym związku.

Dwa stopnie realizacji eschatologicznej, widoczne w słowach Jezusa do Piotra: Dokąd Ja idę, ty teraz ze Mna pójść nie możesz, ale później pójdziesz (J 13,36), są Janowym uzupełnieniem Synoptyków o tyle, że śmierć Jezusa w koncepcji Czwartej Ewangelii jest powrotem do Ojca ${ }^{17}$.

Ewangelista wcześniej już bowiem zaznaczył, że Jezus wiedział o swoim odejściu do Ojca: „że nadeszła godzina Jego, by przeszedł z tego świata do Ojca” (J 13,1$)^{18}$, by otrzymać tam należną chwałę. Jego odejście wiąże się więc ściśle z byciem w rzeczywistości odmiennej od ziemskiej, której istotą jest głęboka relacja międzyosobowa między Nim i Ojcem. W tę samą rzeczywistość pra-

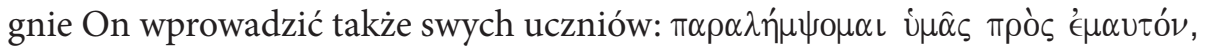

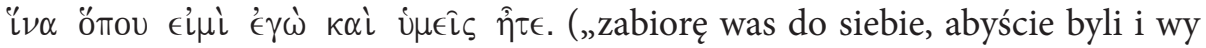
[tam], gdzie Ja jestem") (J 14,3). Istotą ich nowej egzystencji będzie zatem życie $\mathrm{w}$ głębokiej relacji z Bogiem ${ }^{19} \mathrm{i}$ w relacji między samymi uczniami. Jest to zapowiedź powstania wspólnoty zbawionych, trwającej zarówno w jedności z Ojcem i Synem, jak i zjednoczonej z sobą. Sama zapowiedź zabrania uczniów tam, gdzie On, wydaje się jasno ukierunkowywać myśl na odniesienie tych treści do trzech pozostałych określeń, zdających się mieć na pierwszy rzut oka znaczenie topograficzne. Wskazuje ona bowiem jednoznacznie, że bycie z uwielbionym

15 Niektórzy egzegeci zwracają jednak uwagę, że idea „przyjścia” Chrystusa w godzinie śmierci w Biblii w ogóle się nie pojawia. Np. W.A. Brindle, Biblical Evidence, s. 140.

16 R. Brown, Giovanni, s. 753.

17 Por. H. van den Bussche, Jean, s. 396. W pytaniu Piotra skierowanym do Jezusa w sprawie „przyszłego losu” umiłowanego ucznia, który doczeka się za swojego życia paruzji Chrystusa, widoczne są ślady motywu rychłej paruzji, cechującej starsze teksty NT. Por. H. Langkammer, Życie po śmierci, s. 199.

18 Por. J 7,33.

19 Ową ścisłą więź wyraża wpierw zaimek zwrotny '́f $\mu$ utóv (siebie) poprzedzony przy-

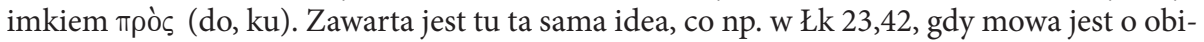
etnicy Jezusa danej z krzyża tzw. „dobremu łotrowi”: „Zaprawdę powiadam ci: Dziś będziesz ze Mną w raju”. Słowa „ze Mną” ( $\mu \epsilon \tau$ ’ '́foû) mówią nie tylko o zwykłym byciu, ale o udziale w nowym, radosnym życiu. Użyty w Łk 23,42 przyimek $\mu \in \tau \alpha ́$ (meta) z dopełniaczem jest o wiele silniejszy od zwykłego w takich przypadkach przyimka oúv (syn) z celownikiem, przynajmniej w języku wcześniejszym od koine. Jego pierwszy źródłosłów łączy się z „byciem w środku, pomiędzy” ( $\mu \epsilon \in \sigma o \varsigma$ - mesos, jak niemieckie mit z Mitte). Por. J. Dupont, $\Sigma Y N$

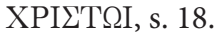


Panem i braćmi stanowi istotę ich nowej egzystencji. Chociaż ewangelista nie podaje żadnych innych szczegółów, to niewątpliwie słowa te, jak słusznie zauważa A. Jankowski, odsłaniają jakiś „egzystencjalny rodzaj szczęścia”20.

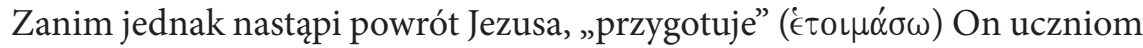
tę docelową rzeczywistość. Przygotowanie polegać będzie na wypełnieniu przez Jezusa woli Ojca w dziele zbawczym poprzez mękę, śmierć i zmartwychwstanie. On pierwszy musi przebyć drogę, którą później podążać mają uczniowie. Idea ta znana jest także autorowi Hbr 2,10; 6,20, a św. Paweł wyrazi ją zwięźle, mówiąc, że Chrystus „zmartwychwstał jako pierwszy spośród tych, co pomarli” (1 Kor 15,20). Być może autor Czwartej Ewangelii zaczerpnął myśl o przygotowaniu miejsca $\mathrm{z}$ typologii Księgi Wyjścia. Bo jak Bóg poprzedzał lud Izraela po wyjściu z Egiptu, by szukać dla niego miejsca (por. Pwt 1,33), tak i Jezus poprzedzałby uczniów w wejściu do domu Ojca. Takie ujęcie zakłada konieczność zaistnienia nowych okoliczności umożliwiających uczniom przyszłe, ostateczne przebywanie razem z Jezusem. Zatem „miejsce”, do którego ze sobą weźmie Jezus swoich uczniów, będzie istotną nagrodą eschatologiczną zbawionych ${ }^{21}$.

Ta właśnie rzeczywistość zostaje określona jeszcze dwoma innymi wyrażeniami, a mianowicie: „domem Ojca” i „mieszkaniami”22. J. Gnilka zaznacza jednak, że o ile obraz „mieszkań” w niebie nosi charakter apokaliptyczny ${ }^{23}$, o tyle określenie „dom Ojca” posiada już koloryt wybitnie chrześcijański ${ }^{24}$. Analiza tych określeń niewątpliwie choć w pewnym stopniu pozwoli wzbogacić opis tej nowej rzeczywistości.

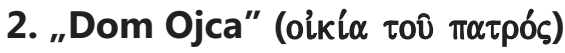

Wyrażenie „dom Ojca” pojawia się w Ewangelii Janowej dwukrotnie $(2,16$;

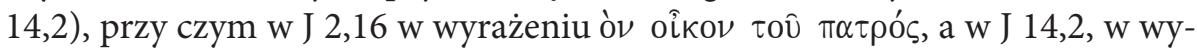

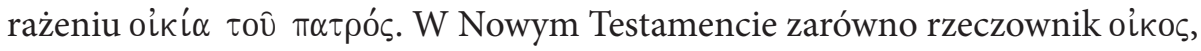
jak i oíkı $\alpha$, są już synonimami i znaczą tyle, co: dom, mieszkanie, lokum, domo-

20 A. Jankowski, Eschatologia, s. 240.

21 O miejscu (topos) w niebie mówi też Ap 12,8, w kontekście strącenia z nieba Smoka i jego aniołów: „już się miejsce (topos) w niebie dla nich nie znalazło”. W niebie więc nie ma nikogo, kto nie trwa w zjednoczeniu z Bogiem.

22 J. Gnilka, Teologia, s. 389.

23 P. Volz, Jüdische Eschatologie, s. 256-260.

24 Zauważa on przy tym, że Jan nie zatrzymuje się dłużej „przy linii prowadzącej do tamtego świata”. J. Gnilka, Teologia, s. 389. 
stwo, czy sami mieszkańcy domu ${ }^{25}$, a więc jak w większości języków, tak i w języku Biblii „dom” oznaczał zarówno materialną budowlę, jak i rodzinę ${ }^{26}$.

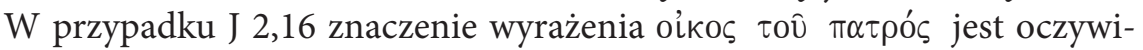
ste: wskazuje ono na świątynię Jerozolimską, którą kramarze uczynili „do-

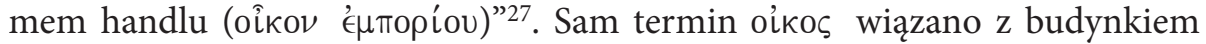
świątyni już we wcześniejszej tradycji biblijnej (np. Iz 65,7; Mk 2,26; Mt 12,4; Łk 6,4). Pozostaje jednak kwestią dyskusyjną, czy w Starym Testamencie idea „Domu Bożego” została przeniesiona ze świątyni na zgromadzenie kultyczne w taki sam sposób, jak nastąpiło przeniesienie znaczenia „domu” jako miejsca zamieszkania na „rodzinę” (wspólnotę) ${ }^{28}$. Pojęcie wspólnoty jako świątyni pojawia się natomiast w dokumentach z Qumran (1QS 5,6; 8,5; 9,6; CD 3,19). W 1 QH 7,8n wspólnota ta nazwana jest wprost „świętym domem zbudowanym na fundamencie prawdy", a 1 QS $8,4-10$, nawiązując do Iz 28,16, wyraźnie łączy nowy „dom” eschatologiczny z zadośćuczynieniem za nieprawości ${ }^{29}$. W J 2,19-21 w kontekście wydarzeń w świątyni, Jezus odniesie już jej obraz do obrazu swego ciała.

Drugi termin, oikí $\alpha$, występujący w J 14,2, nie posiada nigdy, ani w tradycji biblijnej, ani w tekstach pozabiblijnych, żadnych konotacji ze świątynią. Tak w Ewangelii Janowej, jak i w tekstach pozabiblijnych ${ }^{30}$, oznacza on jednak zarówno miejsce zamieszkania $(11,31 ; 12,3)$, jak i wspólnotę życia właściwą rodzinie $(4,53)^{31}$. Zdaniem S. Mędali ${ }^{32}$ użycie w J 14,2 terminu innego niż w J 2,16, może wskazywać na świadomy zabieg ewangelisty, który nie chce mó-

25 J. Goetzmann, House, s. 247. Przed LXX zaznaczała się różnica między tymi słowami: oíкৎ oznaczał „dziedzictwo”, a oíkí „,dom jako taki”. Ibidem.

26 Rdz 12,1; Łk 1,69; 1 Kor 3,9; 1 Tm 3,15. W języku hebrajskim analogia ta opiera się na fakcie, że ten sam rdzeń bana wyraża ideę budowania domu i zakładania rodziny (2 Sm 7,5.13). Por. Dom, w: X. Léon-Dufour, Stownik, s. 224.

27 W Starym Testamencie na określenie świątyni pojawia się podobne określenie, a mianowicie „Dom Boga”, które w NT użyte jest w Mk 2,26.

28 J. Goetzmann, House, s. 247.

29 „Kiedy nastanie to w Izraelu, Rada Zrzeszenia będzie trwała w prawdzie jako wieczna roślina, święty dom dla Izraela, Zgromadzenie najświętsze dla Aarona, świadkowie prawdy wobec sądu, wybrani przez Boże upodobanie do pokuty za ziemię i oddania bezbożnym ich zapłaty. To jest mur wypróbowany, drogocenny kamień węgielny, którego fundamenty się nie zachwieją i nie ruszą ze swego miejsca. To jest najświętszy przybytek Aarona... oraz dom doskonałości i prawdy w Izraelu. Oni pokutując za ziemię i ogłaszając wyrok nad bezbożnością, zostaną przyjęci z upodobaniem i przewrotności [już] nie będzie”.

30 оikí, w: An Intermediate Greek-English Lexicon, s. 545.

31 J. Mateos, J. Barreto, Il Vangelo di Giovanni, s. 590.

32 S. Mędala, Ewangelia, s. 89. 
wić o wymiarze materialnym terminu oikí $\alpha$, lecz zwrócić uwagę czytelnika na wymiar duchowy, związany z relacjami międzyosobowymi. Takie rozumienie nie było obce tradycji judaistycznej. Zwrot „dom Ojca” nabrał głęboko duchowego i eschatologicznego znaczenia już w judaistycznych tekstach apokaliptycznych. Dla Filona z Aleksandrii „dom ojcowski” oznaczał on prostu „niebo” ( De somniis, I, 43, par. 256) ${ }^{33}$, a przebywanie w domu Ojca, w rozumieniu tej tradycji, było równoznaczne z doświadczaniem stanu pokoju, odpoczyn$\mathrm{ku}$ i zbawienia obiecanego sprawiedliwym ${ }^{34}$. Idea domu jako nieba zdaje się być obecna także w 2 Kor 5,1, gdy św. Paweł pisze: „Wiemy bowiem, że jeśli nawet zniszczeje nasz przybytek doczesnego zamieszkania, będziemy mieli mieszkanie od Boga, dom nie ręką uczyniony, lecz wiecznie trwały w niebie". Dla A. Jankowskiego „dom Ojca” jest synonimem „dopełnienia zbawienia”, a pewną analogię widzi on w wyrażeniu św. Łukasza, gdy ten mówi o „wiecznych przybytkach", do których będą przyjmowani wszyscy nagradzani za to, że umieli się właściwie posługiwać „niegodziwą mamoną” (Łk 16,9) ${ }^{35}$. G. Ravasi z kolei w „domu Ojca” będzie widział „symboliczny pałac niebiański, będący znakiem wspólnoty z Bogiem po śmierci" ${ }^{36}$. Stąd też np. C. S. Keener stwierdzi, że „dom Ojca”, o którym mowa w J 14,2, mógłby oznaczać świątynię $(2,16)$, w której Bóg "na wieki zamieszkiwałby ze swoim ludem (Ez 43,7.9; 48,35; por. J 8,35)", przy czym zaznacza, że „Jan zapewne używa tego słownictwa w znaczeniu przenośnym, by opisać przebywanie z Chrystusem w miejscu Bożej obecności” " Wydaje się, że autor Ewangelii mógł, pisząc o „domu Ojca, w którym mieszkań jest wiele", odwoływać się do obrazu zapowiedzianego w J 2,22, gdzie mowa jest o „świątyni ciała”, którą będzie Zmartwychwstały Chrystus. W Nim zaś nastąpi nie tylko „całkowita transformacja kondycji ludzkiej”, ale i „transfiguracja uniwersum"38.

Określenie „dom Ojca” w J 14,2 wydaje się mieć przede wszystkim sens duchowy, wskazujący na rzeczywistość nieba ${ }^{39}$, wiecznie trwałą rzeczywistość, w której wierni zjednoczeni są z Bogiem i ze sobą. S. Mędala stwierdzi lapidar-

33 Takie znaczenie przyjmuje w J 14,2 W. Szczepański, Bóg-Człowiek w opisie Ewangelistów, s. 342.

34 G. Fischer, Die himmilischen Wohnungen, ad locum.

35 A. Jankowski, Teologia, s. 143.

36 G. Ravasi, Zgodnie z Pismem, s. 111.

37 C.S. Keener, Komentarz, s. 216.

38 J. McCaffrey, The House with Many Rooms, s. 56.

39 Nie do przyjęcia ze względu na kontekst pożegnania i śmierci, wydaje się pogląd O. Schaefera, który w „domu Ojca” widzi „Ojcowską sferę potęgi i miłości obejmującą niebo i ziemię". Za R. Schnackenburg, The Gospel, s. 61. 
nie: „dom Boga to relacja między Ojcem a Synem oraz intymne relacje osobowe z Bogiem"40, a I. Gargano odwołując się do doświadczenia ziemskiego, opisze go jako „ognisko domowe, uczucia i bliskie więzi rodzinne [...], poczucie ciepła, intymności, serdeczności, które jest niedefiniowalne, lecz stanowi o czuciu się u siebie w domu"41.

\section{3. „Mieszkanie” (}

Drugim terminem, który należy interpretować przez pryzmat wyrażenia „by-

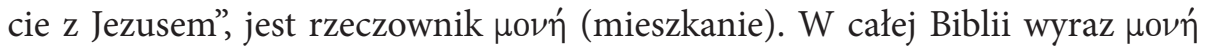
występuje tylko trzy razy ${ }^{42}$, z czego dwukrotnie w Ewangelii według św. Jana $(14,2.23)$. Niektórzy egzegeci uważają, że jego odpowiednikiem jest arm. ' $w n$ ' termin, który odnosił się do miejsca postoju podróżnego, zatrzymującego się na nocleg lub odpoczynek ${ }^{43}$. Takie bowiem znaczenie miał gr. $\mu$ ov żytnej literaturze greckiej, np. u Herodota i Eurypidesa ${ }^{44}$. Jednak w tekście Janowym "mieszkanie” to stoi w opozycji do dotychczasowego, tymczasowego miejsca pobytu uczniów na ziemi. Stąd L. Stachowiak rozumie je w J 14,2 jako miejsce „trwałego pobytu”, w odmiennej od ziemskiej rzeczywistości, a nie jako doraźne miejsce wytchnienia. Wskazuje przy tym, że sama idea takiego miejsca była już dobrze znana $\mathrm{w}$ apokryficznej literaturze międzytestamentalnej ${ }^{45}$ i rabinackiej ${ }^{46}$, przy czym "koncepcja miejsca wywodzi się z nowego ujęcia starotestamentalnej idei Szeolu, rozumianej w apokaliptyce już nie jako neutralne miejsce pobytu cieniów zmarłych, ale jako miejsce nagrody sprawiedliwych w niebie (bądź kary dla występnych)" ${ }^{47}$. W 1 Księdze Henocha, należącej do apokaliptyki żydowskiej, widzący ma wizję nieba jako wspania-

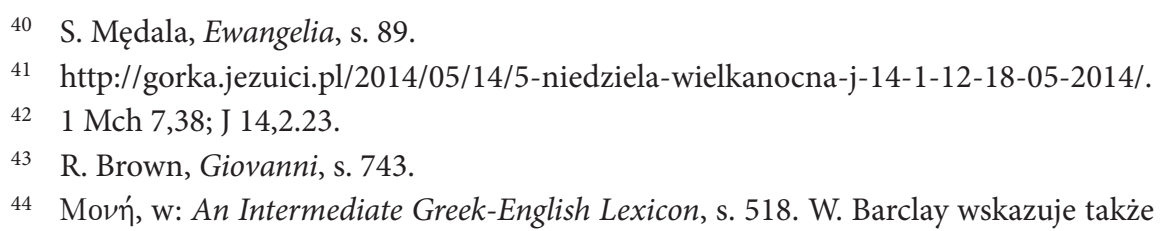
na Pauzaniusza, który rozumie ten termin jako „strefy w drodze”. Por. W. Barclay, Ewangelia, s. 209.

452 Hen $61,1 \mathrm{nn}$.

46 StrBill IV, 2, s. 1016-1036.

47 L. Stachowiak, Ewangelia, s. 311. Takie wyraźne rozróżnienie między duszami złych, które nie mogą wejść do mieszkań, i które muszą się błąkać, a duszami sprawiedliwych, które wchodzą do swojego mieszkania, zostało uczynione np. w 4 Ezd 7,80.85.95. Obrazy ukazujące ostateczne przeznaczenie sprawiedliwych w przeciwieństwie do losu nieprawych zostały zamieszczone również w 2 Hen 61,2-3. 
łego domu, w którego centrum znajduje się tron Boga, otoczony przez dwór niebieski (1 Hen 16,10-23). W niebie widzi on również mieszkanie sprawiedliwych i miejsca odpoczynku świętych (1 Hen 39,4-6; 41,2), które znajdują się w punkcie ekstremalnym nieba $(41,2 ; 45,3)$. Także HenSłow 41,2 wyraża przekonanie, że „w przyszłym świecie... jest wiele mieszkań przygotowanych dla ludzi, dobrych dla dobrych, złych dla złych".

Teksty rabiniczne ${ }^{48}$ obok metafor tych przywołują symbol biblijnego ogrodu Eden. Wskazują przy tym na siedem klas mieszkań sprawiedliwych, podkreślając tym samym zróżnicowany charakter ich egzystencji w raju ${ }^{49}$.

Metafora mieszkań w życiu przyszłym jest również znana w judaizmie hellenistycznym. Odnosi się ona albo do samego Boga, albo do domu - ojczyzny nieśmiertelnej duszy (Filon, Somn. I, 43, par. 256; Conf. Ling. 78; Her. 374; Mos. II 51 par. 288). Natomiast w tekstach gnostyckich i mandejskich pojawiają się określenia: „dom życia”, „dom doskonałości”, „mieszkanie światła”, mieszczące się w schemacie koncepcji dualistycznych, na które w mniejszym lub większym stopniu miał wpływ judaizm ${ }^{50}$.

W Nowym Testamencie idea zamieszkania w niebie pojawia się w Łk 16,9: "Ja też wam powiadam: Pozyskujcie sobie przyjaciół niegodziwą mamoną, aby gdy wszystko się skończy, przyjęto was do wiecznych przybytków ( $\alpha i \omega v i ́ o u s$

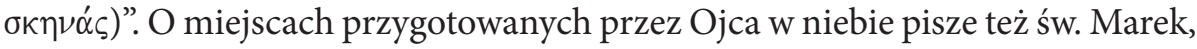
przytaczając słowa Jezusa: „Nie do Mnie jednak należy dać miejsce po mojej stronie prawej lub lewej, ale dostanie się ono tym, dla których zostało przygotowane" (Mk 10, 40). Największe podobieństwo do J 14,2 zawiera jednak tekst Łk 22,29-30. Podczas ostatniej wieczerzy, a więc tak, jak w Ewangelii Janowej, Jezus ogłasza: „Dlatego i Ja przekazuję wam królestwo, jak Mnie przekazał je mój Ojciec: abyście w królestwie moim jedli i pili przy moim stole oraz żebyście zasiadali na tronach, sądząc dwanaście pokoleń Izraela”.

Tradycja patrystyczna sięgająca co najmniej św. Ireneusza, w wyrażeniu „wiele mieszkań” widziała aluzję do różnych stopni doskonałości niebiańskich, to znaczy do wyższych i niższych partii nieba ${ }^{51}$. Orygenes widział w tych

48 Por. StrBill IV, 2, s. 1016-1036.

49 R. Fabris, Giovanni, s. 590, przypis 14.

50 G. Fischer, Die himmilischen Wohnungen, ad locum.

51 Św. Ireneusz o wykładzie starszych pisał: „Oni mówią, że istnieje różnica między mieszkaniami dla tych, którzy przynieśli owoc stokrotny, dla tych, którzy przynieśli owoc sześćdziesięciokrotny, i tymi którzy przynieśli owoc trzydziestokrotny. Pierwsi będą zabrani do nieba, drudzy będą mieszkać w raju, a trzeci będą żyli w mieście. To jest powód, dla którego oni mówią, że Jezus rzekł: W domu Ojca mojego jest mieszkań wiele”. Zob. Adv haer. $\mathrm{V}, 36$. 
mieszkaniach kolejne przystanki w drodze ku Bogu ${ }^{52}$. W ten sam sposób ro-

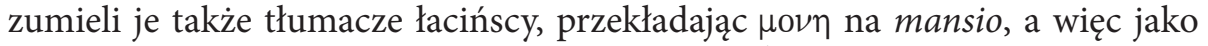
miejsce zatrzymania się, czasowego odpoczynku. Św. Augustyn powie, że „Nikt $\mathrm{z}$ nich nie będzie usunięty $\mathrm{z}$ tego domu, do którego każdy będzie zabrany do mieszkań według swoich własnych zasług" ${ }^{53}$. Podobne wyjaśnienia spotyka się również u gnostyków, według których dusza w swoim wstępowaniu przechodzi przez poszczególne stadia, stopniowo oczyszczając się z tego wszystkiego, co jest materialne $\mathrm{e}^{54}$. W tym duchu interpretowało „liczne mieszkania” wielu dawniejszych egzegetów, wyjaśniając, że należy je rozumieć jako „rozmaite stopnie zasługi i chwały" 55 .

Współczesna egzegeza stwierdza jednoznacznie, że tekst o wielu mieszkaniach w J 14,2 nie zawiera żadnej wskazówki na temat różnic w standardzie między tymi mieszkaniami, lecz jedynie mówi o ich wielości. A. Paciorek podkreśli wprost, że byłoby to sprzeczne z Janową wizją szczęścia ${ }^{56}$. Intencją Jana jest tu jedynie wskazanie na ponowne zjednoczenie z uczniami. Ewentualne inspiracje, zwłaszcza apokaliptyczne, pozwalają wzbogacić ten obraz „mieszkania" o ideę pokoju i szczęścia.

Wydaje się jednak, że niezależnie od źródeł, którymi inspirował się autor Janowej Ewangelii, należy wziąć pod uwagę przede wszystkim jego oryginalną koncepcję rozumienia „mieszkania” ( $\mu$ ov̀̀ $\nu$ ). I choć wprawdzie z J 14,2 dość wyraźnie wynika, że chodzi o eschatologiczną rzeczywistość, której istotą jest definitywne zjednoczenie uczniów z Bogiem ${ }^{57}$, to obraz ten winien zostać uzupełniony o wypowiedź z J 14,23, gdzie mowa jest o „uczynieniu sobie mieszkania" przez Ojca i Jezusa w uczniach miłujących i zachowujących Jego naukę: „Jeśli Mnie kto miłuje, będzie zachowywał moje słowo, a Ojciec mój umiłuje go, i przyjdziemy do niego, i uczynimy u niego mieszkanie"

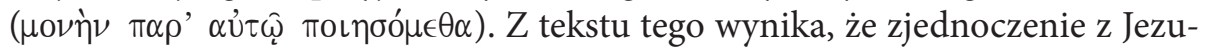
sem dokonuje się po wydarzeniu Wielkanocy, jeszcze w realiach ziemskich (por. J 14,23), a swoją pełną, ostateczną fazę osiągnie wówczas, gdy uczeń będzie już, jak wcześniej zapowiadał Jezus, razem ze swoim Panem: „a gdzie Ja jestem, tam będzie i mój sługa" (J 12,26) ${ }^{58}$. W słowach tych podkreślona zostaje wartość obecnego, teraźniejszego zjednoczenia w wierze z Chrystusem, którego paruzja

\footnotetext{
52 De principiis II, IX; PG 11,246). Zob. też u św. Tomasza z Akwinu, In Jo. 14 lec., I,3.

53 In Jo. Tr. LXVII, 2.

54 Np. Mand Lit, 139:9nn.

55 W. Szczepański, Bóg-Człowiek w opisie Ewangelistów, s. 342.

56 A. Paciorek, Ewangelia umiłowanego ucznia, s. 352.

57 R. Schnackenburg, The Gospel, s. 61.

58 Por. J 17,24.
} 
będzie oczywistą konsekwencją ${ }^{59}$. Obecność Ojca i Syna w wierzącym stanowi poniekąd antycypację lub wręcz realizację życia wiecznego chrześcijanina. Miłość dążąca ze swej natury do zjednoczenia, wyzwala tęsknotę i pragnienie trwałego zjednoczenia z Ojcem przez uwielbionego Chrystusa za sprawą Ducha Świętego ${ }^{60}$. Wydaje się zatem, że teksty te należy traktować nierozłącznie, gdyż „między przebywaniem pełnym chwały w domu Ojca (w. 2), a obecnością Osób Trójcy Świętej w duszy chrześcijanina istnieje ścisła łączność i korelacja. Czynnikiem łączącym, a zarazem warunkiem obecności Boga w człowieku wierzącym jest Słowo i absolutna wierność ucznia wobec Niego, skonkretyzowana w miłości”61. Z J 14,23 można wnioskować, że „mieszkaniami” stają się ci wszyscy, którzy z miłością przyjmują i pragną zachowywać naukę Jezusa. Tym, którzy miłują Jezusa i zachowują Jego przykazania został obiecany Paraklet - „Duch prawdy”, aby był z nimi zawsze ${ }^{62}$. W eschatonie to właśnie oni będą tworzyć rzeczywistość, którą można określić jako „wiele mieszkań”. Jest to rzeczywistość, w której realizuje się ostateczne, najpełniejsze zjednoczenie uczniów z Ojcem i Jezusem rozpoczęte już tu na ziemi ${ }^{63}$. Podkreślić należy fakt, że mowa jest o indywidualnym zamieszkaniu, o osobowym zjednoczeniu z Ojcem i Jezusem każdego poszczególnego ucznia ${ }^{64}$. „Miejsca” te to zatem przebogata rzeczywistość wiernych doświadczających niewyobrażalnego pokoju i szczęścia w niebie. Takie rozumienie potwierdza także użycie wywodzącego się z tego samego rdzenia czasownika $\mu \in \nu \in \hat{\imath} \nu^{65}$, charakterystycznego dla Czwartej Ewangelii. Najczęściej odnosi się on do bycia, pozostawania lub mieszkania z Jezusem i Ojcem w rzeczywistości pełnej pokoju, bezpieczeństwa, szczęścia. Takie znaczenie pojawia się też $\mathrm{w}$ pewnej inskrypcji nabatejskiej z początku ery chrześcijańskiej, która słowo 'wn' stosuje do opisu „grobu” jako miejsca odpoczynku lub zamieszkania w pokoju po zakończeniu życiowych zmagań ${ }^{66}$.

59 R. Schnackenburg, Das eschatologische, s. 540-544.

60 K. Romaniuk, A. Jankowski, L. Stachowiak, Komentarz praktyczny, s. 536.

61 L. Stachowiak, Ewangelia, s. 319.

62 Zdaniem H. Langkammera, „znamienne jest, że przyjście Ojca i Syna wyprzedzi „przyjście” Parakleta. On także przyjdzie jako „posłany przez Chrystusa od Ojca $(15,26)$. Można więc powiedzieć, że według Jana paruzję Chrystusa zainicjuje Duch Paraklet, wyprzedzając drugie przyjście Chrystusa”. Komentarz teologiczno-pastoralny, s. 450.

63 Wieczna wspólnota wierzących z Bogiem możliwa jest poprzez wiarę. Jest to ta sama perspektywa, która pojawia się w słowach Jezusa skierowanych do Marty: „Rzekł do niej Jezus: «Ja jestem zmartwychwstaniem i życiem. Kto we Mnie wierzy, choćby i umarł, żyć będzie. Każdy, kto żyje i wierzy we Mnie, nie umrze na wieki»” (J 11,25n).

64 H. Langkammer, Komentarz teologiczno-pastoralny, s. 443.

65 Czasownik $\mu \in \mathcal{\epsilon} \hat{\imath} \nu$ występuje w IV Ewangelii 40 razy, w Mt - 3, w Mk - 2, w Łk - 7.

66 C. James, ET 27 (1915-16), s. 427-429. Za: R. Brown, Giovanni, 743 
Mamy zatem w Janowej Ewangelii podwójne rozumienie rzeczownika

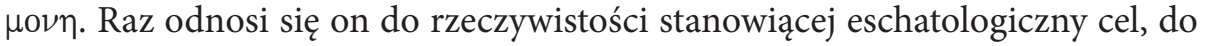
którego Jezus chce zabrać uczniów, a drugim razem jest identyczny z samymi uczniami, w których i z których Bóg uczynił mieszkanie przez Ducha. Rzeczywistość eschatologiczna to niebo, którego istotą jest definitywne zjednoczenie wiernych z Bogiem, przebywanie w pokoju i szczęściu wiecznym.

Oryginalną koncepcją Janową jest połączenie idei miejsca w domu Ojca z ideą mieszkania $(14,2)$, które Bóg uczynił w wierzącym $(14,23)$. To sam wierzący staje się mieszkaniem Ojca i Syna, a po zabraniu przez Jezusa stworzy wraz z wieloma uczniami rzeczywistość, którą będzie dom Ojca. Dom Ojca dotyczy rzeczywistości zbawionych po śmierci, gdyż kontekst wypowiedzi związany z pożegnaniem Jezusa i odejściem do Ojca pozwala jedynie na taką interpretację ${ }^{67}$. "Liczne mieszkania” zatem to zbawieni, o których Apokalipsa powie, że oprócz stu czterdziestu czterech tysięcy opieczętowanych ze wszystkich pokoleń synów Izraela” (Ap 7,4), tworzy je także „wielki tłum, którego nikt nie mógł policzyć, z każdego narodu i wszystkich pokoleń, ludów i języków" (Ap 7,9,a). „Liczne mieszkania” to zjednoczeni z Bogiem w miłości wierni, gdy On zamieszkuje $\mathrm{w}$ nich, a oni $\mathrm{w}$ Nim. To podwójne zjednoczenie $\mathrm{z}$ wiernych z Bogiem i Boga z wiernymi zdaje się najpełniej wyrażać wypowiedź z Pierwszego Listu św. Jana, ściśle związanego z Czwartą Ewangelią ${ }^{68}$ : „Kto trwa w miłości trwa $(\mu \in \in \in \in L)$ w Bogu, a Bóg trwa ( $\left.\mu \mu^{\prime} \nu \in \mathrm{L}\right)$ w nim” $(1 \mathrm{~J} 4,16)$.

Podsumowując zatem powyższe refleksje, można wysunąć wniosek, że określenia „dom Ojca”, „wiele mieszkań”, „miejsce” i „bycie tam, gdzie jest Jezus” odnoszą się do tej samej rzeczywistości, w której już w starożytności widziano niebo. Istotą tej rzeczywistości jest życie zbawionych we wspólnocie z Bogiem, a jej podstawą - jednocząca ją miłość. Wiele mieszkań oznacza wielość zbawionych, którzy stali się mieszkaniami Boga. W nich już na ziemi zamieszkała Trójca Święta, przez co ich życie stało się antycypacją wiecznej chwały w niebie. Jak bowiem wynika z J 14,23 każdy wierzący, w którym przebywa Ojciec i Syn jest mieszkaniem uczynionym przez samego Boga. Te „mieszkania” - miłujący Pana uczniowie i uczennice Jezusa, tworzą w wieczności „Dom Ojca”. Tworzą one już na ziemi wspólnotę miłości, prawdziwy żywy organizm, ciało Chrystusa, świątynię Pana, która w wieczności osiąga swoją pełnię. Jest to wspólnota Boga z ludźmi, która doszła do swego ostatecznego celu, wiecznego szczęścia.

67 R. Schnackenburg, The Gospel, s. 61.

68 H. Langkammer, Wprowadzenie, s. 393. 
Ma rację W. Barclay ${ }^{69}$, gdy pisze, że tekst o wielu mieszkaniach w domu Ojca nie daje wprawdzie podstaw do spekulacji na temat wyglądu nieba, ale uświadamia po raz kolejny prawdę, że „kiedy kochamy kogoś całym sercem, naprawdę żyjący jesteśmy tylko wtedy, gdy jesteśmy z tą osobą". W tekstach Ewangelii Janowej akcent spoczywa bowiem bardziej na samym fakcie niż na próbie opisania go barwnymi obrazami wzorowanymi na apokaliptyce żydowskiej ${ }^{70}$.

\section{Bibliografia}

An Intermediate Greek-English Lexicon Founded upon the Seventh Edition Of Liddell and Scott's Greek-English Lexicon, Oxford 1997.

Bacon B.W., „In My Father's House Are Many Mansions” (J 12. 2), ExpT 43 (1931-32), s. $477-478$.

Barclay W., Ewangelia według św. Jana, t. 2, Warszawa 1986.

Brindle W.A., Biblical Evidence for Imminence of the Rapture, Bibliotheca Sacra 158 (April-June 2001), s. 138-151.

Brown R., Giovanni, Assisi 2005.

Brown R., I Bogiem było Słowo, Kraków 2010.

Bussche van den H., Jean. Commentaire de l'Evangile spiriruel, Bruges 1967.

Fabris R., Giovanni. Traduzione e commento, Roma 2003.

Fischer G., Die himmilischen Wohnungen. Untersuchungen zu Jo 14,2f, (EHS 38), Frankfurt a. M. 1975.

Gnilka J., Teologia Nowego Testamentu, Kraków 2002.

Goetzmann J., House, Build, Manage, Steward, w: DNTT, v. 2, s. 247.

Gundry R., In my Father's House are many Monai (John 14:2), ZNW 58 (1967), s. 68-71.

Jankowski A., Teologia Nowego Testamentu, Kraków 2007.

Keener C.S., Komentarz historyczno-kulturowy do Nowego Testamentu, Warszawa 2010.

Kozyra J., Eschatologia, w: Teologia Nowego Testamentu, t. II. Dzieło Janowe, red. M. Rosik, Wrocław 2008, s. 219-263.

Langkammer H., Wprowadzenie do ksiag Nowego Testamentu, Wrocław 1992.

Langkammer H., Komentarz teologiczno-pastoralny do Biblii Tysiaclecia. Nowy Testament. Ewangelia wg św. Łukasza. Ewangelia wg św. Jana, Poznań 2014.

Langkammer H., Życie po śmierci, Lublin 2004.

Léon-Dufour X., Stownik Nowego Testamentu, Poznań 1981.

Mateos J., Barreto J., Il Vangelo di Giovanni. Analisi linguistica e commento esegetico, Assisi 2000.

McCaffrey J., The House with Many Rooms. The Temple Theme of Jn . 14, 2-3 (AnBib 114), Rome 1988.

W. Barclay, Ewangelia, s. 212.

70

H. Langkammer, Życie po śmierci, s. 199. 
Mędala S., Ewangelia według św. Jana. Rozdziały 13-21, t. IV/ część 2, Częstochowa 2010 .

Neyrey J.H., "Terytoriality” in the Fourth Gospel, BTB 32 (2002), s. 64-74.

Paciorek A., Ewangelia umiłowanego ucznia, Lublin 2000.

Ravasi G., Zgodnie z Pismem. Rok A, Wrocław 1999.

Romaniuk K., Jankowski A., Stachowiak L., Komentarz praktyczny do Nowego Testamentu, t. 1, Poznań-Kraków 1999.

Schnackenburg R., Eschatology in the Fourth Gospel, w: Gospel According to St. John, v. II, New York 1979, s. 426-437.

Schnackenburg R., The Gospel, According to St. John, v. III, New York 1982.

Stachowiak L., Ewangelia według św. Jana. Wstęp. Przekład. Komentarz, Poznań-Warszawa 1975.

Szczepański W., Bóg-Człowiek w opisie Ewangelistów. Nowy synoptyczny przekład czterech Ewangelii w jednej na podstawie tekstu greckiego, Rzym 1914.

Volz P., Jüdische Eschatologie von Daniel bis Akiba, Tübingen 1903. 